\title{
Optimalisasi Lateks Tetesan Lanjut Menggunakan Berbagai Koagulan AnJuran
}

\section{The OPtimization of Continuous Latex Droplet Use the Various RECOMMENDED COAGULANTS}

\author{
Afrizal Vachlepi \\ Balai Penelitian Sembawa - Pusat Penelitian Karet, PT Riset Perkebunan Nusantara (RPN) \\ Jalan Raya Palembang - Pangkalan Balai Km. 29 Kotak Pos 1127, Palembang 30001, Sumatera Selatan \\ Pos el: a_vachlepi@yahoo.com
}

\begin{tabular}{|c|c|}
\hline ARTICLE INFO & Abstract \\
\hline $\begin{array}{l}\text { Article history } \\
\text { Received date } \\
\text { 07 April } 2017 \\
\text { Received in revised form date } \\
18 \text { July } 2019 \\
\text { Accepted date } \\
18 \text { July } 2019 \\
\text { Available online date } \\
\text { May } 2020\end{array}$ & $\begin{array}{l}\text { Natural rubber latex will coagulate naturally about } 4-6 \text { hours after tap- } \\
\text { ping. This coagulation will produce low quality rubber and inconsistent. } \\
\text { In addition, latex will be easily lost by rain because long coagulation } \\
\text { time, especially continuous latex droplet. The use of coagulant in the } \\
\text { continuous latex droplet can reduce yield losses and improve quality. } \\
\text { The purposes were to identify and study the effect of coagulants on the } \\
\text { dry rubber content and technical quality of the rubber from continuous } \\
\text { latex droplet of clone BPM } 24 \text {. The treatments was type of coagulants } \\
\text { consist of formic acid, pure liquid smoke, liquid smoke DS, liquid smoke } \\
\text { DK and control (auto coagulation). Each treatment use } 10 \text { rubber tree } \\
\text { of clone BPM } 24 \text {. The parameters consists of dry rubber content, initial } \\
\text { plasticity (Po), plasticity retention index (PRI), Mooney viscosity, vis- } \\
\text { cosity stability index (SVI), volatile matter content and ash content. The } \\
\text { quality will be analyzed statistically using the completely randomized } \\
\text { design non factorial and will be compared with Indonesian National } \\
\text { Standard 06-1903-2000 about Standard Indonesian Rubber (SIR). The } \\
\text { results showed that the use of coagulant to continuous latex droplet } \\
\text { had significant effect on PRI and Mooney viscosity of rubber. The best } \\
\text { treatment was obtained liquid smoke DS which produce rubber with } \\
\text { quality standards for Po } 36 \text {, PRI } 80.8 \text {, Mooney viscosity } 68 \text {, SVI } 4 \text {, } \\
\text { ash content } 0.27 \% \text { and volatile matter content } 0.48 \% \text {. The coagulated } \\
\text { natural rubber with liquid smoke DS can produce rubber with quality } \\
\text { specifications SIR } 20 \text { grade CV } 70 \text {. } \\
\text { Keywords: Coagulant, Latex, Rubber quality, SIR }\end{array}$ \\
\hline
\end{tabular}




\begin{tabular}{|c|c|}
\hline Kata kunci: & Abstrak \\
\hline $\begin{array}{l}\text { Koagulan, } \\
\text { Lateks, } \\
\text { Mutu karet, } \\
\text { SIR }\end{array}$ & $\begin{array}{l}\text { Lateks karet alam akan menggumpal secara alami sekitar } 4-6 \text { jam } \\
\text { setelah penyadapan. Penggumpalan seperti ini akan menghasilkan } \\
\text { karet bermutu rendah dan tidak konsisten. Selain itu, lateks akan } \\
\text { mudah hilang pada saat hujan karena waktu penggumpalan yang lama, } \\
\text { terutama lateks tetesan lanjut. Penggunaan koagulan pada lateks tetesan } \\
\text { lanjut dapat mengurangi kehilangan hasil dan meningkatkan mutu. } \\
\text { Penelitian ini bertujuan untuk mengetahui dan memelajari pengaruh } \\
\text { penggunaan koagulan terhadap kadar karet kering dan mutu teknis karet } \\
\text { dari lateks tetesan lanjut klon BPM 24. Perlakuan pada penelitian ini } \\
\text { berupa jenis koagulan yang terdiri atas asam format, asap cair murni, } \\
\text { asap cair DS, asap cair DK, dan kontrol (penggumpalan alami). Setiap } \\
\text { perlakuan menggunakan sepuluh pohon karet klon BPM 24. Parameter } \\
\text { pengamatan terdiri atas kadar karet kering (KKK), plastisitas awal (Po), } \\
\text { indeks ketahanan plastisitas (PRI), viskositas Mooney, indeks kesta- } \\
\text { bilan viskositas (SVI), kadar zat menguap, dan kadar abu. Parameter } \\
\text { mutu akan dianalisis secara statistik menggunakan Rancangan Acak } \\
\text { Lengkap (RAL) nonfaktorial dan dibandingkan dengan persyaratan } \\
\text { mutu SNI 06-1903-2000 tentang SIR. Hasil penelitian menunjukkan } \\
\text { bahwa penggunaan koagulan pada lateks tetesan lanjut berpengaruh sig- } \\
\text { nifikan terhadap PRI dan viskositas Mooney karet alam yang dihasilkan. } \\
\text { Perlakuan terbaik diperoleh perlakuan asap cair DS yang menghasilkan } \\
\text { karet dengan standar mutu Po sebesar } 36 \text {, PRI 80,8, viskositas Mooney } \\
\text { 68, SVI 4, kadar abu 0,27\%, dan kadar zat menguap 0,48\%. Karet alam } \\
\text { yang digumpalkan dengan asap cair DS dapat menghasilkan karet den- } \\
\text { gan spesifikasi mutu SIR } 20 \text { grade CV 70. }\end{array}$ \\
\hline
\end{tabular}

C 2020 Widyariset. All rights reserved

\section{PENDAHULUAN}

Lateks adalah getah pohon dari tanaman karet (Hevea brasiliensis sp.) yang diperoleh dengan cara penyadapan (Jayadevan dan Unnikrishnan, 2015). Dalam praktiknya terutama di perkebunan besar, lateks akan dikumpulkan sekitar 2-3 jam setelah proses penyadapan. Waktu pengumpulan yang cepat ini dilakukan untuk menghindari terjadinya penggumpalan. Lateks karet alam akan menggumpal secara alami (auto coagulation) menjadi koagulum (gumpalan lateks) berupa lum sekitar 4-6 jam setelah penyadapan (George dan Jacob, 2000). Walaupun telah dikumpulkan sekitar 2-3 jam setelah penyadapan, pohon karet umumnya masih mengeluarkan lateks. Pohon karet yang disadap biasanya masih mengeluarkan lateks s.d. enam jam setelah penyadapan. Dengan demikian, berarti masih ada lateks yang akan menetes dari pembuluh lateks setelah dikumpulkan. Lateks yang masih menetes setelah proses pengumpulan ini biasanya disebut dengan lateks tetesan lanjut (continuous latex droplet).

Lateks tetesan lanjut ini biasanya dibiarkan menggumpal secara alami. Penggumpalan seperti ini terjadi karena adanya aktivitas mikroorganisme yang menghidrolisasi protein pada partikel karet alam. Lum yang menggumpal secara alami ini umumnya mempunyai mutu yang rendah dan tidak konsisten. Penelitian Zhong et al. (2009) membuktikan bahwa penggumpalan yang dilakukan petani akibat penggunaan koagulan bukan rekomendasi termasuk penggumpalan alami menjadi penyebab rendahnya nilai plastisitas karet alam.

Akibat waktu penggumpalan alami yang relatif lama sekitar 4-6 jam tersebut, lateks tetesan lanjut juga dapat mudah hilang atau terbuang pada saat hujan karena lateks belum menggumpal secara sempurna. Air hujan yang masuk ke dalam mangkuk sadap akan bercampur dengan 
lateks dan lama kelamaan akan memenuhi mangkuk sadap sehingga lateks yang sudah tercampur dengan air hujan akan terbuang ke lingkungan. Kondisi ini sering menjadi keluhan baik petani karet maupun perkebunan besar swasta dan negara terutama saat musim penghujan karena berdampak pada penurunan pendapatan. Lum mangkuk yang seharusnya bisa dikumpulkan keesokan hari, akhirnya tidak dapat diperoleh atau hilang.

Untuk mengantisipasi kehilangan lateks dari tetesan lanjut dan meningkatkan mutu lum yang dihasilkan dapat dilakukan dengan penggumpalan menggunakan bahan penggumpal (koagulan). Koagulan tersebut dimasukkan ke dalam mangkuk sadap setelah proses pengumpulan atau sebelum lateks tetesan lanjut memenuhi mangkuk sadap. Lateks tetesan lanjut akan langsung menggumpal ketika kontak dengan koagulan. Penggunaan koagulan pada lateks tetesan lanjut diharapkan dapat menjadi salah satu solusi baik di perkebunan rakyat (petani) maupun di perkebunan besar sehingga kehilangan produksi akibat hujan dapat dikurangi. Beberapa koagulan anjuran yang dapat digunakan antara lain asam format atau asam semut, asap cair murni, dan formula asap cair (Solichin et al., 2012) seperti asap cair Deorub Super (DS) dan asap cair Deorub K (DK). Koagulan tersebut sudah terbukti menghasilkan karet bermutu baik sesuai dengan persyaratan Standar Nasional Indonesia (SNI) 06-1903-2000 tentang Standard Indonesian Rubber (SIR).

Lasminingsih (2012) menyatakan bahwa jenis klon tanaman karet secara umum dibedakan menjadi dua, yaitu klon penghasil lateks dan lateks-kayu. Beberapa klon rekomendasi penghasil lateks antara lain BPM 24, PB 260, IRR 112, dan IRR 118. Klon BPM 24 merupakan klon yang dikembangkan dan ditanam cukup luas di Indonesia. Kelebihan klon ini diban- dingkan klon lainnya, antara lain potensi produktivitas cukup tinggi sekitar dua ton karet kering/ha/tahun dan menghasilkan karet bermutu baik.

Penelitian ini bertujuan untuk mengetahui dan memelajari pengaruh penggunaan koagulan anjuran terhadap kadar karet kering dan mutu teknis karet yang dihasilkan dari lateks tetesan lanjut yang berasal dari klon BPM 24. Dengan penggunaan koagulan pada mangkuk sadap ini diharapkan lateks tetesan lanjut dapat lebih cepat menggumpal sehingga kehilangan lateks akibat hujan dapat diminimalisasi.

\section{METODE}

Penelitian ini dilakukan di kebun riset dan Laboratorium Teknologi Pengolahan Balai Penelitian Sembawa - Pusat Penelitian Karet pada Maret s.d. Juni 2016. Bahan yang digunakan terdiri atas lateks tetesan lanjut yang diperoleh dari kebun riset Balai Penelitian Sembawa, asam format teknis (asam semut), asap cair murni, asap cair DK dan asap cair DS, serta $\mathrm{P}_{2} \mathrm{O}_{5}$ dari Merck. Peralatan yang digunakan antara lain mangkuk sadap, mesin creper, gilingan terbuka (open mill), oven, rapid plastimeter, Mooney viskometer, neraca digital, stopwatch, dan muffle furnace.

Perlakuan yang diberikan pada penelitian ini berupa jenis koagulan yang terdiri atas asam format, asap cair murni, asap cair DS, asap cair DK, dan kontrol (penggumpalan alami). Parameter mutu yang diamati pada penelitian ini terdiri atas kadar karet kering (KKK), plastisitas awal (Po), indeks ketahanan plastisitas (plasticity retention indek/PRI), viskositas Mooney, indeks kestabilan viskositas (stability viscosity index/SVI), kadar zat menguap, dan kadar abu. Parameter mutu akan dianalisis secara statistik menggunakan Rancangan Acak Lengkap (RAL) non-faktorial dan dilanjutkan dengan uji lanjutan Jarak 
Berganda Duncan (DMRT). Hasil pengujian mutu karet juga dibandingkan dengan persyaratan mutu yang tercantum dalam Standar Nasional Indonesia (SNI) 06-19032000 tentang Standard Indonesian Rubber/ SIR terutama untuk spesifikasi mutu SIR 20 (Tabel 1).

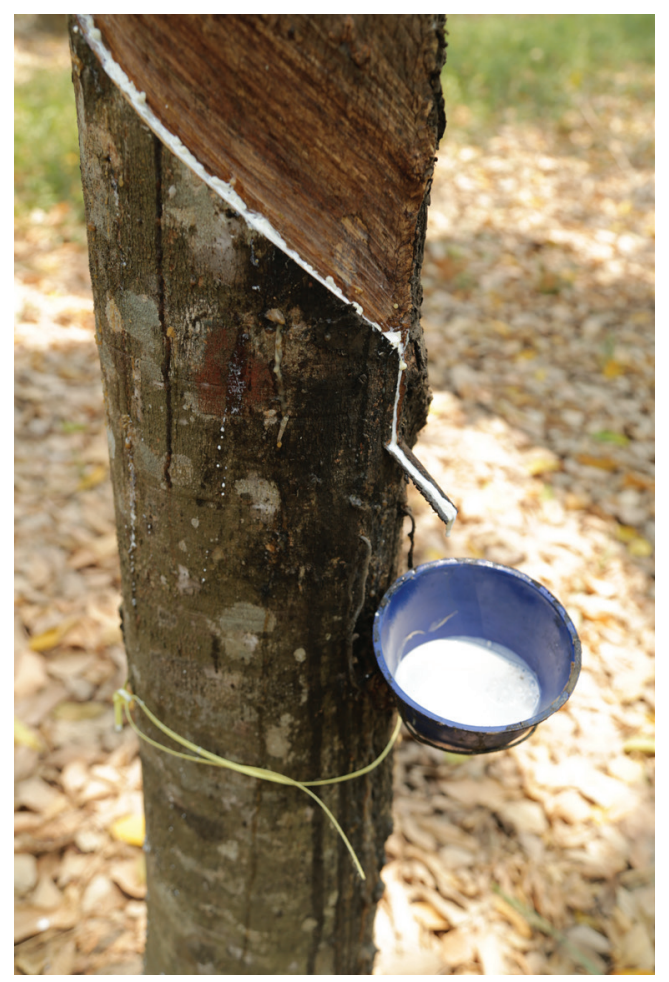

Gambar 1. Lateks/getah pohon karet dalam mangkuk yang diberikan perlakuan berbagai jenis koagulan

Tabel 1. Spesifikasi mutu karet alam SIR 20 berdasarkan SNI 06-1903-2000.

\begin{tabular}{|c|c|}
\hline \multirow{2}{*}{ Spesifikasi / (asal bahan olah) } & SIR 20 \\
\hline & koagulum \\
\hline Kadar kotoran,\% Maks (b/b) & 0,20 \\
\hline Kadar abu, \% Maks (b/b) & 1,00 \\
\hline Kadar zat menguap, \% Maks (b/b) & 0,80 \\
\hline PRI, Min & 50 \\
\hline Po, Min & 30 \\
\hline Nitrogen $(N)$, Maks (b/b) & 0,60 \\
\hline ASHT, Maks & - \\
\hline Viskositas Mooney (ML (1+4)100*) & - \\
\hline \multicolumn{2}{|c|}{ *)Tanda pengenal tingkatan Batasan viskositas mooney } \\
\hline $\mathrm{CV}-50$ & $45-55$ \\
\hline $\mathrm{CV}-60$ & $55-65$ \\
\hline $\mathrm{CV}-70$ & $65-75$ \\
\hline
\end{tabular}

Sumber: (Badan Standardisasi Nasional, 2000).

\section{Prosedur penelitian}

Lateks tetesan lanjut yang digunakan pada penelitian ini berasal dari hasil penyadapan sepuluh pohon karet untuk setiap perlakuan. Berarti total pohon karet yang digunakan dalam penelitian berjumlah 50 pohon karet jenis klon BPM 24. Klon karet BPM 24 termasuk ke dalam klon anjuran dengan metabolisme sedang (Sumarmadji et al., 2005). Setiap pohon karet diasumsikan menghasilkan lateks tetesan lanjut sekitar $150 \mathrm{ml}$ per sadap. Sebelum koagulan dimasukkan, mangkuk sadap terlebih dahulu dibersihkan dari kontaminan seperti daun dan ranting. Setelah itu, koagulan baru dimasukkan ke dalam mangkuk sadap sesuai dengan dosis anjuran Pusat Penelitian Karet. Rekomendasi penggunaan koagulan anjuran dapat dilihat pada Tabel 2.

Tabel 2. Rekomendasi penggunaan koagulan anjuran.

\begin{tabular}{cccc}
\hline $\begin{array}{c}\text { Jenis } \\
\text { koagulan }\end{array}$ & Konsentrasi & $\begin{array}{c}\text { Dosis anjuran } \\
\text { (ml per liter } \\
\text { lateks) }\end{array}$ & $\begin{array}{c}\text { Dosis penggunan } \\
\text { per mangkuk } \\
\text { sadap }\end{array}$ \\
\hline $\begin{array}{c}\text { Asam } \\
\text { format }\end{array}$ & $2 \%$ & $60 \mathrm{ml}$ & $9 \mathrm{ml}$ \\
\hline $\begin{array}{c}\text { Asap cair } \\
\text { murni }\end{array}$ & $10 \%$ & $100 \mathrm{ml}$ & $15 \mathrm{ml}$ \\
\hline $\begin{array}{c}\text { Asap cair } \\
\text { DS }\end{array}$ & $5 \%$ & $100 \mathrm{ml}$ & $15 \mathrm{ml}$ \\
\hline $\begin{array}{c}\text { Asap cair } \\
\text { DK }\end{array}$ & $5 \%$ & $100 \mathrm{ml}$ & $15 \mathrm{ml}$ \\
\hline
\end{tabular}

Sumber: (Suwardin et al., 2014)

Untuk mendapatkan lateks tetesan lanjut, mangkuk sadap dibiarkan di pohon karet selama 24 jam. Lateks tetesan lanjut selanjutnya akan menggumpal di dalam mangkuk sadap yang disebut dengan lum mangkuk. Setelah dibiarkan 24 jam, lum mangkuk dikumpulkan untuk digiling menggunakan mesin creper menjadi crepe (lembaran karet alam) dan dikeringkan menggunakan oven pada suhu $\pm 105{ }^{\circ} \mathrm{C}$ sampai kering. Crepe kering selanjutnya dianalisis kadar karet kering (KKK) dan 
mutu teknisnya berupa plastistas awal (Po), indeks ketahanan plastisitas (plasticity retention index/PRI), viskositas Mooney, indeks kestabilan viskositas (stability viscosity index/SVI), kadar abu, dan kadar zat menguap. Analisis kadar karet kering dilakukan berdasarkan SNI 06-2047-2002 tentang bahan olah karet (Badan Standardisasi Nasional, 2002). Analisis semua parameter mutu teknis dilakukan berdasarkan prosedur kerja yang tercantum dalam SNI 06-1903-2000.

KKK lum mangkuk dihitung menggunakan persamaan sebagai berikut.

$$
K K K(\%)=\frac{X_{1}}{X_{0}} \times 100 \%
$$

dimana:

$$
\begin{array}{ll}
\mathrm{KKK} & =\text { kadar karet kering }(\%) \\
\mathrm{X}_{0} & =\text { bobot basah lum mangkuk (gram) } \\
\mathrm{X}_{1} & =\text { bobot kering crepe }(\text { gram })
\end{array}
$$

\section{HASIL DAN PEMBAHASAN Kadar Karet Kering (KKK)}

KKK merupakan istilah yang sudah umum digunakan dalam industri pengolahan karet alam (Kumar et al., 2007). KKK adalah persentase kandungan partikel karet alam (poliisoprena) yang terdapat pada bahan olah karet dalam hal ini crepe. Kadar karet kering (KKK) lum mangkuk dengan berbagai jenis koagulan yang berasal dari tetesan lanjut disajikan pada Gambar 2. Hasil analisis statistik menunjukkan bahwa penggunaan berbagai jenis koagulan tidak memberikan pengaruh yang signifikan terhadap KKK lum mangkuk yang dihasilkan.

Walaupun secara statistik tidak berpengaruh secara signifikan, seperi terlihat pada Gambar 1, KKK lum mangkuk yang digumpalkan dengan bahan penggumpal (koagulan) lebih tinggi dibandingkan tanpa koagulan atau alami (kontrol). KKK lum mangkuk yang digumpalkan dengan menggunakan koagulan sekitar 40,44-41,33\%. Sedangkan KKK lum mangkuk kontrol hanya $39,72 \%$. Hasil ini menunjukkan bahwa penggunaan koagulan pada lateks tetesan lanjut akan menghasilkan lum mangkuk yang mempunyai KKK lebih tinggi.

KKK yang lebih tinggi tersebut disebabkan kemampuan koagulan dalam melepaskan atau mengeluarkan air dari dalam lum mangkuk karet terutama asap cair. Hasil penelitian (Solichin 2007) menyatakan bahwa asap cair mempunyai

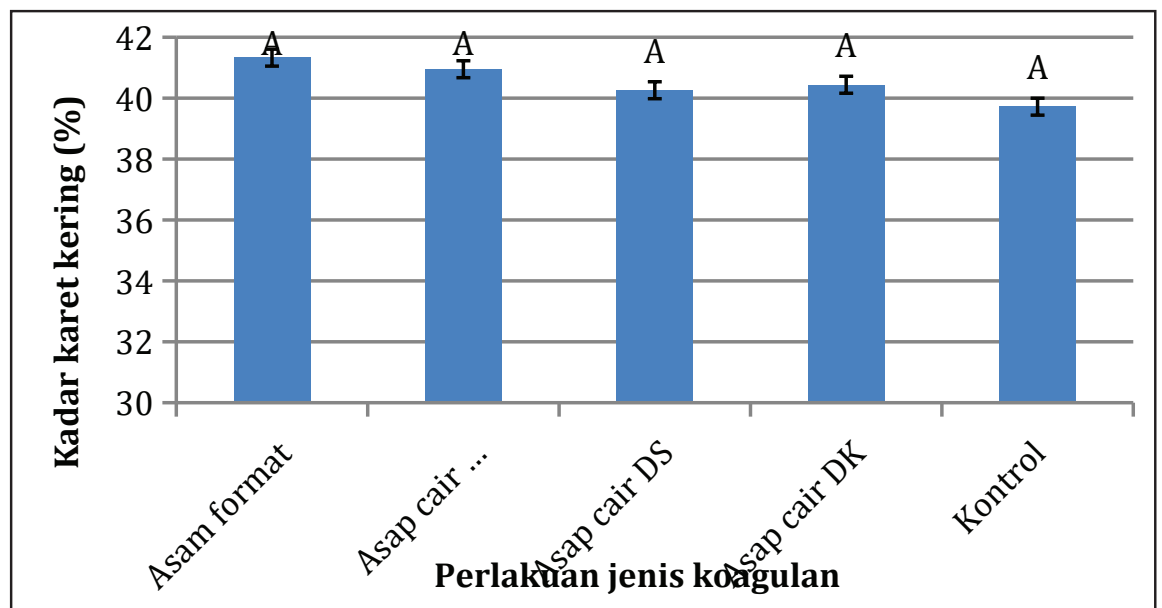

Gambar 2. Kadar karet kering (KKK) lum mangkuk/koagulum dari klon karet BPM 24 terhadap berbagai jenis koagulan

Keterangan:angka-angka yang diikuti huruf yang sama pada setiap kolom berarti tidak berbeda pada uji lanjutan Jarak Berganda Duncan (DMRT) pada tingkat kepercayaan $95 \%(\dot{\alpha}=0,05)$ 
kemampuan melepaskan air yang disebut dengan syneresis effect. Kemampuan koagulan asap cair tersebut sangat menguntungkan karena dapat mengurangi biaya pengangkutan (transportasi) dari kebun karet ke pabrik. Air yang terdapat di dalam karet alam akan dihilangkan selama proses pengolahan. Dengan KKK yang tinggi berarti kadar air di dalam karet rendah. Semakin sedikit air yang diangkut, maka semakin banyak padatan karet (lum kering) yang bisa diangkut.

Keuntungan lainnya dari KKK yang tinggi adalah proses pengeringan dapat dilakukan lebih cepat karena jumlah air yang harus diuapkan atau dihilangkan sudah lebih sedikit. Pengeringan merupakan proses penting untuk mengurangi kandungan air bahan dan memastikan mutu produk yang konsisten (Xiang et al., 2015). Proses pengeringan yang cepat ini akan meningkatkan efisiensi biaya produksi. Tham et al. (2014) dan Ekphon et al. (2012) menyatakan bahwa proses pengeringan merupakan salah satu proses yang memerlukan energi cukup besar dalam industri karet alam. Dengan semakin rendahnya kadar air, maka waktu pengeringan menjadi lebih singkat sehingga energi yang diperlukanpun menjadi lebih rendah atau lebih efisien.

\section{Mutu teknis karet alam}

Parameter mutu teknis karet alam yang diamati terdiri atas nilai plastisitas awal (Po), indeks ketahanan plastisitas (PRI), nilai viskositas Mooney, indeks kestabilan viskositas (SVI), kadar abu, dan kadar zat menguap.

\section{Plastisitas karet alam}

Hasil analisis parameter mutu plastisitas awal (Po) dan indeks ketahanan plastisitas (PRI) karet alam berbagai perlakuan dapat dilihat pada Tabel 3. Plastisitas awal (Po) adalah ukuran plastisitas karet yang secara tidak langsung memperkirakan panjangnya rantai polimer molekul atau berat molekul (BM) karet. PRI adalah suatu ukuran ketahanan karet terhadap pengusangan (oksidasi) pada suhu tinggi.

Nilai PRI diukur dari besarnya keliatan karet mentah yang masih tertinggal apabila sampel tersebut dipanaskan selama 30 menit pada suhu $140{ }^{\circ} \mathrm{C}$. Nilai PRI merupakan persentase keliatan karet sesudah dipanaskan dibandingkan dengan keliatan sebelum dipanaskan dan ditentukan dengan alat Wallace Plastimeter. Nilai Po dan PRI merupakan parameter dasar untuk menentukan mutu karet (Achmadi et al., 2015). Persyaratan minimal untuk kedua

Tabel 3. Hasil analisis mutu teknis karet alam dari lateks tetesan lanjut dengan berbagai perlakuan jenis koagulan.

\begin{tabular}{lccccc}
\hline \multirow{2}{*}{ Spesifikasi Mutu } & \multicolumn{5}{c}{ Jenis koagulan } \\
\cline { 2 - 6 } & Asam format & $\begin{array}{c}\text { Asap cair } \\
\text { murni }\end{array}$ & Asap cair DS & Asap cair DK & Kontrol \\
\hline Plastisitas awal / Po & $44 \mathrm{a}$ & $40 \mathrm{a}$ & $36 \mathrm{a}$ & $38 \mathrm{a}$ & $41 \mathrm{a}$ \\
\hline Indeks ketahanan plastistas / PRI & $82,8 \mathrm{a}$ & $76,0 \mathrm{ab}$ & $80,8 \mathrm{a}$ & $79,0 \mathrm{a}$ & $69,4 \mathrm{~b}$ \\
\hline Viskositas Mooney & $77 \mathrm{a}$ & $73 \mathrm{ab}$ & $68 \mathrm{~b}$ & $72 \mathrm{ab}$ & $74 \mathrm{ab}$ \\
\hline Indeks kestabilan viskositas/SVI & $4 \mathrm{a}$ & $4 \mathrm{a}$ & $6 \mathrm{a}$ & $3 \mathrm{a}$ & $5 \mathrm{a}$ \\
\hline Kadar abu (\%) & $0,26 \mathrm{a}$ & $0,28 \mathrm{a}$ & $0,27 \mathrm{a}$ & $0,21 \mathrm{a}$ & $0,36 \mathrm{a}$ \\
\hline Kadar zat menguap (\%) & $0,55 \mathrm{a}$ & $0,41 \mathrm{a}$ & $0,48 \mathrm{a}$ & $0,50 \mathrm{a}$ & $0,47 \mathrm{a}$ \\
\hline Keterangan: angka-angka yang diikuti huruf yang sama pada setiap baris berarti tidak berbeda pada uji lanjutan Jarak \\
Berganda Duncan (DMRT) pada tingkat kepercayaan 95\% $(\dot{\alpha}=0,05)$
\end{tabular}


parameter tercantum pada SNI 06-19032000 (Tabel 1).

Seperti terlihat pada Tabel 3 diketahui bahwa plastisitas awal (Po) karet alam tidak dipengaruhi oleh perlakuan koagulan. Nilai Po karet alam semua perlakuan berkisar antara 36-44. Nilai Po tersebut memenuhi persyaratan mutu SNI 06-1903-2000 (Tabel 1) dimana syarat mutu karet ekspor SIR 20 adalah minimal 30. Tingginya nilai Po semua perlakuan disebabkan proses pengolahan dilakukan secara langsung tanpa melalui proses penyimpanan terlebih dahulu atau bahan baku lum masih dalam kondisi segar. Dengan cara proses pengolahan tersebut, pertumbuhan mikroorganisme yang dapat menurunkan mutu karet dapat ditekan sehingga mutu karet tetap baik salah satunya nilai Po.

Berdasarkan Tabel 3 diketahui bahwa penggunaan koagulan pada lateks tetesan lanjut (lum mangkuk) berpengaruh nyata terhadap nilai indeks ketahanan plastisitas (PRI) karet alam. Nilai PRI lum mangkuk yang menggunakan koagulan secara umum lebih tinggi dibandingkan kontrol. Nilai PRI lum mangkuk dengan koagulan berkisar antara 76,0-82,8, sedangkan lum mangkuk kontrol hanya sekitar 69,4. Walaupun secara statistik nilai PRI karet alam berbeda nyata, tetapi secara umum karet alam semua perlakuan memenuhi persyaratan mutu SNI 06-1903-2000 dimana syarat minimal PRI untuk karet ekspor SIR 20 minimal 50.

Tingginya nilai PRI karet alam yang digumpalkan menggunakan koagulan anjuran terjadi karena kemampuan koagulan tersebut dalam mencegah karet alam teroksidasi pada suhu tinggi. Solichin et al. (2005) menyatakan bahwa asap cair mengandung sekitar 67 jenis senyawa yang dapat berfungsi sebagai antibakteri, antioksidan, pemberi warna coklat, dan bau asap yang khas. Senyawa fenol atau turunannya yang terdapat pada asap cair dapat berfungsi sebagai antioksidan yang akan melindungi molekul karet pada suhu tinggi sehingga nilai PRI-nya tetap tinggi (Solichin, 2005 dan Prasertsit et al., 2011).

\section{Viskositas karet alam}

Parameter mutu viskositas yang diamati pada penelitian ini berupa viskositas Mooney dan indeks kestabilan viskositas (stability viscosity index/SVI). Parameter viskositas Mooney menggambarkan pajang rantai molekul karet. Parameter mutu ini memegang peranan penting dalam proses pencampuran ketika pembuatan kompon, baik untuk tingkat dispersi bahan-bahan kimia kompon di dalam karet maupun energi yang diperlukan untuk penggilingan di mesin pencampur. Viskositas yang terlalu tinggi menyebabkan tingginya konsumsi daya mesin pemroses. Sebaliknya jika viskositasnya sangat rendah, menyebabkan rendahnya gaya geser pada pencampuran yang berakibat material cenderung beraglomerasi maka homogenitasnya rendah (Maspanger 2008).

Viskositas Mooney biasanya digunakan juga sebagai indikator teknologi untuk mengetahui karakterisasi partikel karet ditinjau dari kemampuannya saat pemrosesan lebih lanjut, termasuk pada saat pembuatan kompon (Zheleva 2013). Berbeda dengan viskositas, parameter SVI lebih menggambarkan perubahan nilai viskositas Mooney karet alam selama penyimpanan sebelum karet alam diproses lebih lanjut menjadi barang jadi karet. Nilai SVI ini menunjukkan seberapa stabil viskositas karet alam selama penyimpanan. Hasil analisis viskositas Mooney dan SVI karet berbagai perlakuan dapat dilihat pada Tabel 3.

Berdasarkan hasil analisis statistik pada tingkat kepercayaan 95\% (Tabel 3) diketahui bahwa penggunaan koagulan berpengaruh terhadap viskositas Mooney. 
Nilai viskositas Mooney tertinggi diperoleh dari karet alam yang dihasilkan dari penggumpalan lateks tetesan lanjut menggunakan asam format, yaitu sebesar 77 . Nilai viskositas Mooney yang tinggi ini mencerminkan telah banyak rantai molekul yang telah mengalami percabangan dan membentuk jaringan tiga dimensi (Suparto et al., 2009) dibandingkan perlakuan lain. Fenomena ini terjadi karena adanya proses reaksi ikatan silang antargugus aldehida pada rantai poliisoprena. Ikatan silang yang terbentuk tersebut akan membuat rantai poliisoprena menjadi lebih panjang yang ditandai dengan pengerasan pada karet alam. Pengerasan karet alam mengindikasikan nilai viskositas Mooney yang tinggi.

Nilai viskositas Mooney karet alam yang digumpalkan dengan koagulan asap cair secara umum lebih rendah dibandingkan kontrol (Tabel 3), yaitu berkisar antara 67-73. Nilai viskositas paling rendah diperoleh karet alam dengan koagulan asap cair DS, yaitu sebesar 67. Hasil analisis ini menunjukkan bahwa koagulan asap cair terutama asap cair DS mampu mencegah terjadinya proses pengerasan pada karet alam. Kemampuan asap cair mencegah proses pengerasan disebabkan adanya senyawa antioksidan seperti phenol yang terdapat dalam asap cair. Dengan nilai viskositas Mooney berkisar antara 67-73, karet alam yang diproses dari tetesan lanjut dengan koagulan asap cair dapat diproduksi menjadi karet ekspor dengan mutu yang lebih tinggi, yaitu SIR 20 dengan grade CV 70 sesuai SNI 06-1903-2000 (Tabel 1).

Indeks kestabilan viskositas (SVI) karet alam yang diperoleh dari hasil penggumpalan lateks tetesan lanjut tidak dipengaruhi ini oleh penggunaan jenis koagulan (Tabel 3). Nilai SVI karet alam dari proses penggumpalan lateks tetesan lanjut secara umum berkisar antara 3-6. Angka ini mengindikasikan bahwa viskositas karet alam tersebut cukup stabil baik selama penyimpanan maupun pengangkutan dari pabrik karet remah ke pabrik ban. Nilai SVI tertinggi diperoleh karet alam dengan koagulan asap cair DS sebesar 5,5 poin.

Berdasarkan hasil analisis viskositas Mooney dan nilai SVI, nilai viskositas Mooney karet alam dengan koagulan asap cair DS yang awalnya sebesar 67 (setelah proses pengolahan) diprediksi akan meningkat menjadi maksimal 73 pada saat akan diproses menjadi kompon karet. Sedangkan karet alam kontrol, dengan nilai viskositas awal sebesar 74 diprediksi akan mengalami perubahan sebesar lima poin menjadi sekitar 79 pada saat akan diproses menjadi kompon karet.

Perubahan nilai viskositas Mooney tersebut terjadi karena adanya reaksi ikatan silang pada partikel karet alam. Reaksi ikatan ini terjadi secara alami yang ditandai dengan kenaikan nilai viskositas Mooney. Solichin (1995) menyatakan bahwa mekanisme proses pengerasan adalah terjadinya ikatan silang gugus aldehida pada rantai poliisoprena karet alam (Gambar 3).

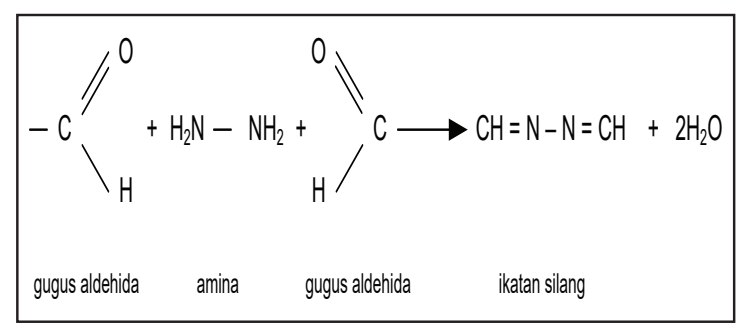

Gambar 3. Mekanisme reaksi ikatan silang penyebab terjadinya pengerasan pada karet alam

Karet alam dengan nilai viskositas Mooney yang tetap rendah (nilai SVI juga rendah) dapat mempersingkat proses mastikasi sehingga lebih efisien dalam penggunaan energi. Energi yang dibutuhkan untuk proses mastikasi ini sebesar 33-35\% dari total energi pada saat pembuatan kompon karet (Solichin dan Immanuel, 1991). Mastikasi adalah proses pelunakan (plastisasi) karet alam dengan tujuan untuk memu- 
dahkan pencampuran dengan bahan kimia menjadi lebih merata (Alam 2008). Karet alam yang lunak, ditandai dengan viskositas Mooney yang rendah, akan memudahkan pencampuran dengan bahan kimia tambahan pada saat pembuatan kompon karet.

\section{Kadar abu}

Penggunaan koagulan pada lateks tetesan lanjut tidak memberikan pengaruh yang signifikan terhadap kadar abu karet alam yang dihasilkan (Tabel 3). Walaupun tidak berpengaruh secara signifikan, karet alam dari lateks tetesan lanjut tanpa koagulan (kontrol) mempunyai kadar abu paling tinggi dibandingkan karet alam dengan bahan penggumpal, yaitu sebesar $0,36 \%$.

Tingginya kadar abu di dalam karet alam kontrol disebabkan masuknya bahan-bahan bukan karet ke dalam lateks tetesan lanjut. Lateks tanpa bahan penggumpal (kontrol) tersebut mempunyai waktu penggumpalan yang lama mencapai 4-6 jam sehingga memungkinkan bahan-bahan lain masuk ke dalam mangkuk sadap yang berisi lateks. Tanpa adanya koagulan, lateks tetesan lanjut yang ada di dalam mangkuk sadap masih berupa cairan sehingga bahan-bahan lain bukan karet dapat mudah tercampur dengan lateks sebelum menggumpal secara sempurna. Bahan-bahan lain bukan karet dapat berupa ranting, daun atau kotoran halus yang jatuh dari atas pohon karet.

Berbeda dengan karet alam dengan koagulan, kadar abu karet alam tersebut lebih rendah dibandingkan kontrol dimana hanya sekitar 0,21-0,28\%. Rendahnya kadar abu karet alam dengan koagulan ini dikarenakan lateks tetesan lanjut akan langsung menggumpal ketika kontak dengan koagulan di dalam mangkuk sadap. Gumpalan lateks (koagulum) yang berupa padatan lebih sulit tercampur dengan ba- han-bahan lain bukan karet dibandingkan lateks dalam bentuk cair. Penggunaan koagulan pada lateks tetesan lanjut memberikan keuntungan berupa dapat meminimalisasi kemungkinan masuknya bahan-bahan lain bukan karet pada lateks.

Seperti terlihat pada Tabel 3 juga diketahui bahwa hasil analisis kadar abu karet alam dari semua perlakuan berkisar antara $0,21-0,36 \%$. Hasil ini menunjukkan bahwa kadar abu semua perlakuan memenuhi persyaratan mutu seperti yang tercantum dalam SNI 06-1903-2000 tentang SIR (Tabel 1). Berdasarkan SNI tersebut dipersyaratkan bahwa kadar abu karet alam dengan spesifikasi mutu SIR 20 maksimal $1 \%$.

\section{Kadar zat menguap}

Kadar zat menguap dari karet alam setiap perlakuan ditampilkan pada Tabel 3. Perlakuan penggunaan koagulan pada lateks tetesan lanjut tidak memberikan pengaruh yang signifikan terhadap terhadap kadar zat menguap karet alam. Hal ini terjadi karena dosis penggunaan koagulan sangat kecil sehingga tidak memberikan pengaruh yang cukup signifikan terhadap kadar zat menguap karet. Kadar zat menguap di dalam karet alam sebagian besar berasal dari serum lateks dan zat-zat lain yang mudah menguap seperti bahan aditif dalam hal ini koagulan. Adanya zat yang mudah menguap di dalam karet alam, selain dapat menyebabkan bau busuk, juga memudahkan tumbuhnya jamur yang dapat menimbulkan kesulitan pada waktu mencampurkan bahan-bahan kimia ke dalam karet pada waktu pembuatan kompon tersebut terutama untuk pencampuran karbon black pada suhu rendah (Badan Standardisasi Nasional, 2000).

Seperti terlihat pada Gambar 8 kadar zat menguap semua perlakuan berkisar antara $0,41-0,55 \%$. Angka ini secara 
umum memenuhi standar mutu seperti yang dipersyaratkan SNI 06-1903-2000 (Tabel 1) dimana jumlah maksimal kadar zat menguap karet ekspor untuk spesifikasi mutu SIR 20 adalah maksimum 0,80\%. Hasil ini menunjukkan bahwa penggunaan koagulan anjuran berupa asam format dan asap cair pada lateks tetesan lanjut tidak akan meningkatkan kadar zat menguap.

\section{KESIMPULAN DAN SARAN}

\section{Kesimpulan}

Penggunaan koagulan (bahan penggumpal) pada lateks tetesan lanjut berpengaruh signifikan terhadap parameter mutu indeks ketahanan plastisitas (PRI) dan viskositas Mooney karet alam yang dihasilkan. Perlakuan terbaik diperoleh perlakuan asap cair DS yang menghasilkan karet dengan standar mutu Po sebesar 36, PRI 80,8, viskositas Mooney 68, SVI 4, kadar abu $0,27 \%$, dan kadar zat menguap 0,48\%. Karet alam yang digumpalkan dengan asap cair DS dapat menghasilkan karet dengan spesifikasi mutu SIR 20 grade CV 70.

\section{Saran}

Penelitian dalam skala yang lebih besar perlu dilakukan terutama terkait dengan analisis ekonomis dari penggunaan koagulan dalam mengoptimalkan lateks tetesan lanjut.

\section{UCAPAN TERIMA KASIH}

Penulis ingin menyampaikan terima kasih kepada Dr. Heru Suryaningtyas sebagai Kepala Balai Penelitian Sembawa-Pusat Penelitian Karet atas izin dan dukungan yang diberikan sehingga penelitian ini dapat dilaksanakan melalui kegiatan rutin inhouse Balai Penelitian Sembawa tahun 2016.

\section{DAFTAR ACUAN}

Achmadi, S.S, Cifriadi, A., dan Hidayah, M.N. 2015. "Redistilat asap cair dari cangkang kelapa sawit dan aplikasinya sebagai koagulan karet alam." Jurnal Penelitian Karet 33 (2): 183-92.

Alam, A. 2008. "Mastikasi dan dasar proses pencampuran." In Makalah Kursus Teknologi Barang Jadi Karet, 61-62. Bogor: Balai Penelitian Teknologi Karet.

Badan Standardisasi Nasional. 2000. "Standar Nasional Indonesia (SNI) 06-1903-2000 tentang Standard Indonesia Rubber (SIR)," 1-2.

- 2002. Standar Nasional Indonesia (SNI) 06-2047-2002.

Ekphon, A., Ninchuewong, T., Tirawanichakul, S., dan Tirawanichakul, Y. 2012. "Drying model, shrinkage and energy consumption evaluation of air dried sheet rubber drying system for small enterprise." Advanced Materials Research 622-623: 1135-39. https://doi.org/10.4028/www.scientific.net/AMR.622-623.1135.

George, P.J dan Jacob, C.K. 2000. "Natural rubber agromanagement and crop processing." Rubber Research Institute of India. 378-379.

Jayadevan, J dan Unnikrishnan, G. 2015. "Modification of natural rubber latex by grafting." Rubber Science 28 (2): 178-96.

Kumar, R.R, Hussain, S.N., and Philip, J. 2007. "Measurement of dry rubber content of natural rubber latex with a capacitive transducer." Journal of Rubber Research 10 (1): 17-25.

Lasminingsih, M. 2012. "Pembangunan kebun entres." In Saptabina Usahatani Karet Rakyat, Keenam, 15-21. Balai Penelitian Sembawa.

Maspanger, D.R. 2008. "Sifat fisik karet." In Makalah Kursus Teknologi Barang Jadi Karet, 75-76. Bogor: Balai Penelitian Teknologi Karet. 
Prasertsit, K., Rattanawan, N., dan Ratanapisit, J. 2011. "Effects of wood vinegar as an additive for natural rubber products." Songklanakarin Journal of Science and Technology 33 (4): 425-30.

Solichin, M, Suwardin, D, dan Vachlepi, A. 2012. "Pengolahan karet alam." In Saptabina Usahatani Karet Rakyat, Keenam, 105-14. Balai Penelitian Sembawa.

Solichin, M., Pramuaji, I., dan Anwar, A. 2005. "Deorub K sebagai pembeku dan pencegah timbulnya bau busuk karet." In Workshop Bahan Pembeku Asap Cair Yang Ramah Lingkungan.

Solichin, M dan Immanuel, V. 1991. "Kajian pembuatan sit angin yang viskositasnya dimantapkan." Buletin Perkaretan 7 (2): 94-100.

Solichin, M. 1995. "Pemantapan viskositas Mooney karet alam dengan natrium fenolat, natrium metabisulfit dan asetaldehida." Universitas Gadjah Mada.

. 2005. Optimasi produksi asap cair yang ramah lingkungan sebagai koagulan lateks, penanganan limbah bau dan cair dalam pengolahan karet remah dan sit asap. Balai Penelitian Sembawa.

- 2007. Studi pengolahan sit asap (RSS) dan karet remah dengan menggunakan sinar matahari sebagai pengeringan awal dan asap cair sebagai pembeku dan pengawet. Sembawa: Balai Penelitian Sembawa.
Sumarmadji, Karyudi, Siregar, T.H.S., dan Junaidi, D. 2005. "Optimasi produktivitas klon karet melalui berbagai sistem eksploitasi." In Prosiding Lokakarya Nasional Pemuliaan Tanaman Karet, 123-40. Balai Penelitian Sei Putih.

Suparto, D., Syamsu, Y., Cipriadi, A., dan Honggokusumo, S. 2009. "Sifat teknis karet remah dengan viskositas Mooney dan kadar gel rendah." Prosiding Lokakarya Pemuliaan Tanaman Karet 2009.

Suwardin, D., Vachlepi, A., Purbaya, M., dan Hanifarianty, S. 2014. "Teknologi pengolahan bokar." In Saptabina Usahatani Karet Rakyat, 109-18.

Tham, T.C., Hii, C.L., Ong, S.P., Chin, N.L., Abdullah, L.C., dan Law, C.L. 2014. "Technical review on crumb rubber drying process and the potential of advanced drying technique." Agriculture and Agricultural Science Procedia 2: 26-32. https://doi. org/10.1016/j.aaspro.2014.11.005.

Xiang Ng, M., Tham, T.C., Ong, S.P., dan Law, C.L. 2015. "Drying kinetics of technical specified rubber." Journal of Information Processing in Agriculture 2: 64-71.

Zheleva, D. 2013. "An attempt for correlation between Mooney viscosity and rheological properties of filled rubber compounds." Journal of Chemical Technology and Metallurgy 48 (3): 241-46.

Zhong, J P., Li, CP., Li, S.D., Kong, L.X., Yang, L., Liao, S.Q., and She, X.D. 2009. "Study on the properties of natural rubber during maturation." Journal of Polymer Materials 26 (3): 351-60. 